\title{
CRÍTICA DE CULTURA NO FEMININO
}

Heloisa Pontes

Analisar as inflexões de gênero no campo intelectual brasileiro, em sua interface com a crítica de cultura e literária, entre os anos de 1920 e 1960, tal é o objetivo do artigo. ${ }^{1}$ Para tanto, vou me centrar nas trajetórias sociais de três mulheres expressivas, que fizeram "nome" como críticas de cultura, ensaístas e, em maior ou menor grau, escritoras: Lúcia Miguel Pereira (1901-1959), Patrícia Galvão (1910-1962), e Gilda de Mello e Souza (19192005). Presenças marcantes, suas carreiras são inseparáveis das parcerias conjugais que estabeleceram ao longo da vida: Lúcia Miguel Pereira com o historiador Otávio Tarquínio de Souza; Patrícia Galvão com os modernistas Oswald de Andrade e Geraldo Ferraz; Gilda de Mello e Souza com o crítico e estudioso da literatura, Antonio Candido.

As três pertencem a gerações distintas e cobrem o espectro político da época: do comunismo ao socialismo, no caso de Patrícia Galvão, passando pelos círculos dos intelectuais católicos, como Lúcia Miguel Pereira, ou mantendo certa distância destas questões por meio da afirmação de uma identidade intelectual de tipo acadêmico, como Gilda de Mello e Souza, a única dentre elas a cursar a universidade. Além disso, estão situadas nos dois maiores centros de produção intelectual da época: São Paulo e Rio de Janeiro. Na emergente metrópole paulista, encontrava-se Gilda de Mello e Souza; no Rio de Janeiro, então capital política e cultural, Lúcia Miguel Pereira. Patrícia Galvão passou por ambas em momentos precisos de sua trajetória. Acompanhá-las nessas cidades, com uma visada comparativa, permite uma apreensão matizada da dinâmica, da estrutura e dos condicionantes mais amplos que modelaram o campo intelectual. Entre eles, o lugar e o peso da universidade, do jornalismo, das editoras, das modalidades diversas de mecenato público e privado, das redes de família e sua inserção (ou não) nas elites dirigentes.

O recorte cronológico do artigo pauta-se em uma dupla justificativa. A primeira, de ordem biográfica, uma vez que Lúcia Miguel Pereira morreu 
em 1959 e Patrícia Galvão em 1962. A segunda, decorrente de razões internas ao campo intelectual brasileiro. Perfis intelectuais como os de Patrícia, Lúcia e Gilda de Mello e Souza, que transitavam por domínios diversos da produção cultural, tornaram-se cada vez mais raros no cenário de especialização crescente, inclusive da crítica literária, após os anos 1970 (Ramassote 2006). Por fim, cabe enfatizar que a escolha destas três intelectuais não se assenta no critério da representatividade, e sim no fato de serem mulheres excepcionais que inauguraram novas modalidades de inserção e atuação na cena cultural, em meio à vivência de tensões e constrangimentos derivados das relações de gênero. Vistas em conjunto, elas delineiam alguns dos espaços possíveis para a atuação intelectual das mulheres na época. Daí o interesse de enxergá-las em blow-up e, ao mesmo tempo, não perder de vista os contornos do campo intelectual nos decênios de 1930 e 1940, que correspondem aos anos em que estrearam.

\section{Contexto}

A urbanização e a industrialização, signos da modernização pela qual passava o país, aliadas à efervescência política e cultural sem precedentes dos anos de 1920 (atestada pelas greves operárias, pela fundação do Partido Comunista, pela militância católica e pelo movimento tenentista), criaram as condições necessárias para que segmentos restritos das elites e seus agregados das camadas médias, localizados em São Paulo e no Rio de Janeiro, pudessem produzir um conjunto de experimentos culturais modernos, inéditos na história brasileira. "Reencontrando a influência européia por um mergulho no detalhe brasileiro", os modernistas promoveram, segundo Candido (2006:127-129) o "desrecalque localista", contribuindo, assim, para que as nossas deficiências passassem a ser reinterpretadas ora como singularidades, ora como superioridades. $\mathrm{O}$ mulato e o negro foram definitivamente incorporados como temas de estudo e o romance tornou-se instrumento de pesquisa humana e social, ao lado do ensaio não especializado de viés histórico. "O poderoso imã da literatura interferia com a tendência sociológica - concebida mais como ponto de vista do que como pesquisa objetiva da realidade - dando origem àquele gênero misto de ensaio, construído na confluência da história com a economia, a filosofia e a arte, que é uma forma bem brasileira de investigação e descoberta do Brasil" (Candido 2006:137-138).

Gestadas nos anos de 1920, as experimentações modernistas regeramse pela "dialética do localismo e do cosmopolitismo" (Candido 2006:117) e promoveram a atualização em novas bases da cultura brasileira. No entanto, 
foi somente no decênio seguinte, após a eclosão da Revolução de 1930, que tais experiências culturais deixaram de ser uma marca de transgressão, sofrendo, a partir de então, um "processo de rotinização e de normalização" (Candido 1984:27). Os intelectuais, cingidos pelas ideologias políticas do momento, numa polarização aguda entre comunistas, católicos e fascistas, lançaram-se no debate dos problemas sociais do país e voltaram-se para a investigação e o estudo da nossa realidade. "O Brasil começou a se apalpar" (Candido apud Pontes 2001a:6). A realidade brasileira tornou-se o conceitochave do período, encarnando-se nos estudos histórico-sociológicos, políticos, geográficos, econômicos e antropológicos. Pautados por um frenesi de interpretar o passado nacional, explicar e diagnosticar o presente, tais estudos foram veiculados principalmente pelas coleções Brasiliana e Documentos Brasileiros (Pontes 2001b). Ao mesmo tempo em que o mercado editorial acolhia uma parte significativa desses estudos, criava condições para que vários escritores se tornassem profissionais da literatura.

Ao analisar o período, Antonio Candido sublinha a centralidade da Revolução de 1930 no delineamento do novo panorama cultural. Projetando na escala da nação fatos que antes ocorriam no âmbito da região, ela foi um "eixo e um catalisador em torno do qual girou de certo modo a cultura brasileira, catalisando elementos dispersos para dispô-los numa configuração nova" (Candido 1984:27). Tal configuração expressou-se em diversos setores da vida cultural do país: na instrução pública, nas reformas do ensino primário e secundário, na produção artística e literária, nos meios de difusão cultural, na fundação de novas faculdades e das primeiras universidades brasileiras. Tardias em relação às instituições de ensino superior criadas em vários países latino-americanos quando ainda eram parte da América Espanhola, as universidades brasileiras nasceram modernas, em sintonia com os sistemas acadêmicos internacionais. Em suma, uma idéia no lugar certo.

A fundação da Universidade de São Paulo, criada em 1934 e viabilizada com a contratação de professores estrangeiros, ocorreu nesse contexto intelectual de interesse renovado pelo Brasil. Os integrantes da Missão Francesa chegaram à capital paulista para dar vida ao projeto da Universidade de São Paulo. No Rio de Janeiro (com exceção da Universidade do Distrito Federal, fechada no início do Estado Novo, em 1937), eles se fizeram presentes por vias oficiais, com autorização direta do presidente Getúlio Vargas e com a exigência básica de serem ligados à Igreja, para dar conta de um trabalho docente no âmbito de uma universidade sob controle confessional muito mais rígido e estrito. A estadia deles na antiga capital federal, além de curta, teve um "impacto intelectual mais modesto do que aquele exercido pela missão francesa na USP" (Almeida 2001:236). 
Em São Paulo, ao contrário, a contribuição dos franceses foi decisiva para a implantação e a consolidação da Faculdade de Filosofia, Ciências e Letras. E também para impulsionar a ruptura com a mentalidade jurídica vigente nos centros tradicionais de ensino superior do país, de onde até então saía "boa safra de figuras de destaque nas carreiras intelectuais não científicas, em especial literárias". Por serem "treinados nas regras e nos costumes da competição acadêmica européia", empenharam-se em instituir ali "um elenco de procedimentos, exigências e critérios acadêmicos de avaliação, titulação e promoção" (Miceli 2001a:101-102).

Jovens em início de carreira, principalmente aqueles que chegaram antes da guerra - como Maugüé, Lévi-Strauss, Monbeig e Bastide - eles não possuíam maior projeção no meio intelectual francês: davam aulas em liceus ou em faculdades fora de Paris, publicavam nas regióes em que lecionavam (Peixoto 2001:489). O Brasil representava a possibilidade de deslanchar a carreira acadêmica, além de oferecer ao grupo de cientistas sociais uma especialização temática original. Como professores e pesquisadores ajudaram a construir um sistema de produção intelectual, universitário e acadêmico sem raízes fortes na tradição brasileira. À juventude dos professores franceses, somava-se à da Universidade e de seus alunos. Decepções, impasses, esperanças e poucas certezas entrelaçavam-se nos sentimentos dos mestres e de seus alunos.

O depoimento de Claude Lévi-Strauss ilustra bem o estado das coisas que encontrou na recém-criada Faculdade de Filosofia, onde ocupou a Cadeira de Sociologia (1935-1937). Tendo descoberto no Brasil e aos 27 anos a vocação de etnólogo, Lévi-Strauss organizou diversas expedições científicas ao Mato Grosso e à Amazônia, nos períodos das férias letivas, longe do assédio dos estudantes. Sobre eles, afirma o antropólogo,

queriam saber tudo; qualquer que fosse o campo do saber, [mas] só a teoria mais recente merecia ser considerada. Fartos dos festins intelectuais do passado, que de resto só conheciam de ouvido, pois nunca liam as obras originais, mostravam um entusiasmo permanente pelos novos pratos. Seria preciso, no que lhes diz respeito, falar de moda e não de cultura: idéias e doutrinas não apresentavam aos seus olhos um valor intrínseco, eram apenas consideradas por eles como instrumentos de prestígio, cuja primazia tinham de obter. O fato de partilhar uma teoria já conhecida por outros era o mesmo que usar um vestido pela segunda vez: corria-se o risco de um vexame (Lévi-Strauss 1981:97).

Ácida e impiedosa, a avaliação de Lévi-Strauss pode ser lida hoje menos como fonte primária a revelar a situação da Faculdade de Filosofia na 
época e mais como expressão dos sentimentos tumultuados do professor e antropólogo iniciante, formado em outro sistema de pensamento e de trabalho. Suas observações sobre os estudantes e o sistema de ensino brasileiro, ainda que corretas do ponto de vista etnográfico, deixam entrever todo um lado incontido de seu "pré-conceito" em relação à situação que encontrou na universidade recém-criada. Elas sugerem que talvez seja mais fácil para os antropólogos, formados nos centros de produção dos paradigmas da antropologia, explicarem as sociedades indígenas, verdadeiramente outras em relação à Europa, do que aquelas, como a brasileira, que são a um só tempo prolongamento e negação do Velho Mundo. Sobretudo quando se trata de um grupo muito particular dessas sociedades: o dos intelectuais.

A dificuldade de Lévi-Strauss em apreender o que se passava no Brasil em termos de um sistema intelectual distinto culturalmente do seu não se reduz a uma questão de idiossincrasia pessoal. Por isso, sua avaliação pode ser lida como expressão condensada da fala nativa - neste caso, européia sobre o impacto e as decepções decorrentes do esforço de implantar um sistema de trabalho e de pensamento sem um enraizamento maior na tradição nativa dos outros, no caso, brasileira.

Lévi-Strauss não foi, assim, o único a expressar um desconforto em relação ao que se passava no domínio da universidade paulista. Por razões diversas, o modernista Oswald de Andrade (1890-1954) não perdia oportunidade de manifestar sentimentos ambivalentes em relação a seus integrantes. Recusa e admiração, fascínio e ironia mesclavam-se em sua escrita desempenada para caracterizar o estilo "bom-mocismo" e bem comportado dos estudantes universitários. Mesmo quando (bem) surpreendido pelas atividades que vinham fazendo - como a montagem, em 1944, da peça Auto da barca do inferno, de Gil Vicente - ele não abria mão de lhes dar suas alfinetadas. Referindo-se aos universitários que participaram desse espetáculo, no artigo que publicou no jornal O Estado de S. Paulo, afirmou que eles haviam encontrado "seu refúgio brilhante, a sua paixão vocacional talvez. É o teatro. Funcionários tristes da sociologia, quem havia de esperar desses parceiros [...] aquela justeza grandiosa que souberam imprimir [à peça]" (Andrade 1972:65-66). ${ }^{2}$

Com esses elogios o escritor modernista expressou o reconhecimento pela "glória da estréia do grupo universitário que montou Gil Vicente à altura das intenções quinhentistas". Coroamento à parte, ele não perdeu, contudo, a oportunidade para explicitar mais uma vez a ironia em relação à formação universitária dos dirigentes do grupo, os "chato-boys" e "funcionários tristes da sociologia". O incômodo sentido por Oswald, para além das idiossincrasias de sua personalidade avassaladora, sinaliza um aspecto 
mais geral das transformações em curso no campo intelectual paulista. A introdução de novas maneiras de conceber e praticar o trabalho intelectual, promovida pela Universidade, chocava-se com o padrão dominante das carreiras intelectuais da época, construídas na intersecção do jornalismo, da política, da literatura e da vida mundana.

Criada num caldo de cultura em que se misturavam o movimento modernista e sua rotinização, as realizações da arquitetura moderna, as coleções "brasilianas", os projetos de intervenção e de política cultural — como o Departamento de Cultura e o Serviço do Patrimônio Histórico e Artístico Nacional $^{3}$ - a Faculdade de Filosofia, Ciências e Letras da Universidade de São Paulo tornou-se em pouco tempo o centro e o eixo em torno do qual girou a formação de um novo sistema acadêmico de produção intelectual, graças à atuação, no decorrer dos decênios de 1940 e 50, dos membros mais expressivos de seu corpo discente. De um lado, os integrantes do Grupo Clima: Antônio Candido, Gilda de Mello e Souza, Décio de Almeida Prado, Paulo Emílio Salles Gomes, Lourival Gomes Machado, Ruy Coelho, entre outros (Pontes 1998). De outro lado, os cientistas sociais reunidos sob a liderança do sociólogo Florestan Fernandes.

Para aquilatar o tamanho do impacto da Faculdade de Filosofia na vida e na carreira das mulheres que fizeram nome como intelectuais acadêmicas, caso de Gilda de Mello e Souza, basta mencionar que as faculdades de direito e de medicina, ${ }^{4}$ nas quais se formavam os filhos das elites dirigentes da época, eram avessas às pretensões do contingente feminino, que jamais ultrapassou a diminuta cifra de 5\% do corpo discente no período de 1934 a 1949. Porcentagem tanto mais irrisória quando contrastada aos $60 \%$ de mulheres que integravam as turmas de ciências sociais na Faculdade de Filosofia entre 1936 e 1955 (Miceli 2001a:96).

Se a universidade teve um peso importantíssimo no sistema intelectual paulista e foi decisiva na viabilização das carreiras femininas, no Rio de Janeiro ela não alcançou a mesma centralidade. Ali, e por um bom tempo, ela conviveu "com outras vias de acesso à vida pública, sendo, em larga medida, pouco mais que uma agência de obtenção de credenciais para o escalonamento salarial dos ocupantes de postos superiores do serviço público" (Carvalho 2007:24). Na qualidade de capital política do país e de cidade cosmopolita, o Rio de Janeiro abrigava uma sociabilidade intelectual diversa da capital paulista. Academias, livrarias, cafés, bares e redação de jornais e revistas eram os espaços privilegiados de circulação de idéias e de sociabilidade. A partir dos anos 1910, a cidade torna-se "a sede e o laboratório de um grande e forte projeto de militância política, que inegavelmente conduziu a Igreja à situação de um dos mais importantes atores do campo político e 
intelectual" (Gomes 1999:30). Além disso, contava, sobretudo nos anos 30 e na gestão de Gustavo Capanema no Ministério da Educação e Cultura (Schwartzman et alii 1984) com dois pólos centrais de mecenato: o Estado e a Sociedade Felipe d'Oliveira, responsável pela atribuição do prêmio literário mais importante da época. ${ }^{5}$ Formada por uma "composição heterogênea de intelectuais de vários matizes religiosos e ideológicos", cujo ponto em comum era o fato de serem "talentos indiscutíveis, além de possuidores de diferenciados recursos de poder" (Gomes 1999:95), a sociedade reunia nas páginas de seu boletim anual, Lanterna Verde, autores das mais variadas latitudes políticas, de Otávio Tarquínio de Souza, funcionário de alto escalão e historiador autodidata, a escritores comunistas, como Jorge Amado.

Se o mecenato estatal e o trânsito de intelectuais de procedências políticas distintas por espaços e redes em comum davam o tom da sociabilidade carioca, na capital paulista, em franco processo de metropolização, as marcas do mecenato privado (Galvão 1981) e da universidade em formação, aliadas às experimentações no plano do teatro, das ciências sociais, das artes plásticas e do cinema (Arruda 2001), singularizam a experiência cultural da cidade. Nela, o teatro, como mostra Gilda de Mello e Souza, antecipouse "aos estudos sociais, encarregando-se da tarefa realizada no Nordeste pelo romance". Tal fenômeno se explica pelas alterações que ocorriam em passo acelerado na estrutura social da cidade. "Ao mesmo tempo que a ordem antiga se rompia, a urbanização se processava de maneira acelerada. A decadência de todo um setor da sociedade [a oligarquia agrária] era compensada pelo desenvolvimento de outro e a perda de prestígio do fazendeiro se cruzava com a ascensão econômica e social do imigrante. Presenciavase, sem fôlego, uma substituição simétrica de estilos de vida e não o lento desaparecimento de um mundo cuja agonia se pudesse acompanhar com lucidez" (Mello e Souza 1980:110).

A retradução dessa experiência social no plano formal da linguagem deu-se em São Paulo pela via da dramaturgia e das ciências sociais e não pelo romance. Paradoxalmente mais "moderna" e mais "provinciana" que o Rio de Janeiro, ela se tornou, com a criação do Teatro Brasileiro de Comédia em 1948, o pólo modernizador do teatro brasileiro, ofuscando a cena teatral carioca por mais de uma década. Mas se São Paulo não produziu romancistas da estatura literária dos romancistas nordestinos, foi no Rio de Janeiro que vários deles encontraram guarida para virar escritores em tempo integral. Contaram, para tanto, com editoras dispostas a investir na publicação de seus livros, entre elas a José Olympio, a mais renomada da época e centro de sociabilidade de escritores reconhecidos (Sorá 1998) ou ligados "ao grupo de intelectuais orgânicos do regime, recém cooptado pelo governo central, 
sem esquecer toda uma categoria [de autores] que obtinham a chancela da casa pelo fato de pertencerem aos anéis burocráticos em operação junto aos aparelhos do Estado" (Miceli 2001b:65).

\section{Lúcia Miguel Pereira: intelectual autodidata}

Bem relacionada, Lúcia era filha de um médico conceituado, Miguel Pereira (professor da Faculdade de Medicina do Rio de Janeiro), prima em segundo grau de Antonio Candido de Mello e Souza e, pelo lado materno, pertencia a uma família de mulheres cultas. "Sua mãe e sua avó eram grandes leitoras, assim como (coisa rara no século XIX brasileiro) suas duas bisavós" (Candido 2004:128). Mais conhecida por seus trabalhos como crítica e historiadora da literatura, entre eles, Machado de Assis (1936), ${ }^{6}$ História da literatura brasileira: prosa de ficção (1950), A vida de Gonçalves Dias (1952), Lúcia Miguel Pereira escreveu quatro romances: Maria Luísa (1933), Em surdina (1933), Amanhecer (1938), Cabra-cega (1954). ${ }^{7}$ A primeira incursão na crítica literária se deu aos 28 anos em Elo (1927-29). A revista divulgava a experiência de alunas e ex-alunas do Colégio Notre Dame do Sion ligadas ao movimento de reação católica, de perfil conservador, que se organizara no Rio de Janeiro após a conversão de Jackson de Figueiredo em 1916. Fundador da revista A ordem (1921) e do Centro D. Vital (1922), inspirado no pensamento anti-revolucionário europeu do século XIX, afinado com os movimentos políticos de direita que despontaram nas primeiras décadas do século XX, Jackson de Figueiredo foi o principal mentor de um pensamento católico que extrapolou a arena política e contribuiu para a invenção do intelectual católico (Pinheiro 2007:35-36).

Lúcia estreou na revista do colégio onde cursara o primário e o ginásio no mesmo ano em que o crítico Alceu Amoroso Lima assumia a liderança do Centro D. Vital. Sintonizada com as diretrizes do pensamento católico, ela seguia a "convenção estabelecida para uma representante da elite, senão econômica, social: dedicava-se a discretas atividades assistenciais" (Mendonça 1992:xvii), lecionava na Missão da Cruz e na escola mantida pelo colégio Sion para crianças pobres, escrevia críticas literárias ocasionais, lia e estudava muito. Autodidata, não cursou a universidade, mas perseguiu a carreira de crítica literária, ensaísta e escritora. Sua inserção no campo intelectual carioca aconteceu de fato aos 32 anos, quando passou a escrever regularmente no Boletim de Ariel (1933-37) e a colaborar com a Revista do Brasil e com os suplementos literários do Correio da Manhã e do Estado de S. Paulo. 
Católica e contrária às dimensões materialistas do socialismo, resolutamente antifascista, Lúcia foi ao longo da vida diluindo a posição religiosa, embora mantivesse o cristianismo no plano das convicções pessoais. Após os anos 1930, "a influência católica já se reduzira, tanto no plano doutrinário quanto na vida pessoal - de divorcista, que se uniu a um homem desquitado, múltipla heresia para os padrões da época" (Mendonça 1992:xix). Intelectual com vôo próprio, reconhecida por seus méritos, Lúcia beneficiou-se também da parceria com o historiador Otávio Tarquínio de Souza (1889-1959). Quando se casou com ele em 1940, em cerimônia realizada no Uruguai - um dos poucos países que reconheciam o divórcio e permitiam a oficialização de casamentos entre pessoas desquitadas, caso de Otávio - Lúcia já era uma mulher madura. Tinha 39 anos, 12 a menos que o marido. Bem posicionado na vida política e intelectual, Otávio foi presidente (1918-32) e ministro (1938-43) do Tribunal de Contas da União. Foi também o primeiro presidente da Associação Brasileira de Escritores, diretor da Revista do Brasil (1938-43) e da coleção Documentos Brasileiros, publicada pela José Olympio. Entre os autores mais editados nessa coleção, encontravam-se Sérgio Buarque de Holanda, Gilberto Freyre, Otávio Tarquínio de Souza e Lúcia Miguel Pereira, a única mulher que alcançou tal distinção num sistema de produção intelectual marcadamente masculino (Pontes 2001b:472).

No final dos anos 1950, ela estava preparando "um livro alentado sobre a condição feminina no Brasil, em perspectiva histórica" (Candido 2004:129), mas que não chegou a ser editado. Por decisão da autora, em testamento público, nenhum inédito dela deveria ser "publicado após a minha morte, senão por Octávio Tarquínio de Souza, que disporá de todos os meus manuscritos. Na sua falta, deverão meus herdeiros queimar todos os papéis, assim literários como íntimos, que encontrarem" (Pereira 1992:339). ${ }^{8}$ Falecida num acidente de avião, junto com o marido, sua instrução foi cumprida pela família.

Impossibilitados de conhecer o conteúdo desse livro, temos, no entanto, pistas suficientes para repertoriar o interesse de Lúcia pelo assunto em seus ensaios e romances. Longe de uma adesão à causa feminista, tais escritos revelam a um só tempo o fascínio pelo assunto e a tentativa de manter um distanciamento crítico em relação a ele. Na condição de autodidata, sobretudo na fase em que se mostrou mais afinada com o pensamento católico, Lúcia recusava-se a explicar a situação das mulheres pelo prisma da discriminação de gênero. Exemplo disto é o artigo "Crítica e feminismo", publicado no jornal Correio da Manhã, em 1944, no qual ela avalia A room of one's own, de Virginia Woolf: "delicioso como graça de espírito e finura", com "recursos extraordinários de malícia e vivacidade", apesar de "todas as deficiências que lhe dá o seu caráter feminista". O esforço da escritora 
inglesa para mostrar as limitações sofridas pelas mulheres, que teriam sido "excluídas de tudo o que é bom na vida", tem, na opinião da crítica, uma dimensão de inverdade e de coisa ultrapassada. A ponto de lhe parecerem "tão distantes de nós como as saias compridas, os leques, os desmaios. Coisas fora da moda, embora graciosas, que completam bem a mistura de segurança intelectual e de fragilidade sofisticadamente feminina de Virginia Woolf". Enfática na restrição ao postulado geral da autora sobre a condição das mulheres, Lúcia afirma ainda que ela teria confundido nesse ensaio a ordem psicológica e a social. Por isso, "as condições que estabelece como as únicas indispensáveis ao trabalho intelectual feminino - liberdade de pensamento e um mínimo de bem-estar material - não pertencem às chamadas conquistas femininas. São direitos essenciais da pessoa humana, homem ou mulher, artista ou operário" (Pereira 2005:114).

Tal avaliação foi emitida onze anos depois do lançamento do romance de estréia de Lúcia, Maria Luísa (1933), editado por Augusto Frederico Schmidt, poeta e intelectual católico, ligado ao Centro Dom Vidal e seu grande amigo. Publicado no mesmo ano de Parque industrial, de Patrícia Galvão, o livro passa ao largo da discussão feminista e das questões sociais e políticas que agitavam a intelectualidade na época. E também das inovações formais introduzidas pelos modernistas. Recebido sem entusiasmo pela crítica, o romance é interessante como documento da visão da autora estreante na tentativa de ficcionalizar a experiência das mulheres de seu mundo social, não por um mecanismo de identificação, mas sim de distanciamento.

O romance é centrado na vida de Maria Luísa - "boa filha, esposa exemplar, mãe cuidadosa, excelente dona de casa". Católica, ela freqüenta a igreja e participa de trabalhos assistenciais, por força do hábito e dos deveres esperados de uma mulher na sua condição social. O casamento com Artur segue a rotina das afeições domesticadas. Até que um incidente trivial faz com que Maria Luísa sinta pela primeira vez uma fissura no casamento. E isso vai repercutir nas férias em família, passadas em Petrópolis. Durante a semana, Artur volta ao Rio para trabalhar. Após encontrar um amigo da juventude, Flávio, que estava fora do Brasil há muitos anos, ele aproveita a ausência da mulher para se divertir e adia o retorno a Petrópolis. Usa como desculpa compromissos inesperados e inadiáveis, os quais irão acontecer de fato, obrigando-o a cancelar a viagem no final de semana em que planejava levar o amigo para se juntar à família. Artur fica no Rio e Flávio parte sozinho para o hotel em que Maria Luísa e os filhos estavam hospedados. Surpresa com a notícia de que o marido não viria e com o fato de conhecer Flávio nessa circunstância, Maria Luísa vai aos poucos cedendo aos seus encantos, desenvoltura e cosmopolitismo. 
Na segunda parte, as férias já terminaram e Maria Luísa está em casa com os filhos e o marido, alterada e alarmada com o que sucedera entre ela e Flávio. O que aconteceu entre eles no plano amoroso e sexual é apenas insinuado. Após se dar conta de que tudo não passara de um jogo de sedução, Maria Luísa rompe com Flávio "para salvar uns restos de dignidade". Daí em diante o livro registra a crise avassaladora da protagonista. O caso que tivera com o amigo do marido, vivido de início com a intensidade da descoberta de "um mundo nunca suspeitado, um mundo livre, colorido, brilhante", enquanto o seu e o único que conhecera até então "parecia desmoronar-se", despertara nela "uma mulher desconhecida, revoltada contra a mesmice da vida, vibrante de loucas aspirações". Mas o que era descoberta converte-se em autoflagelação. Ela, que sempre dominara o certo e o errado no plano da moralidade e dos valores, vê seu mundo estilhaçado e entrega-se ora à depressão e à prostração, ora ao trabalho doméstico e aos filhos de maneira compulsiva.

Enredo banal, linguagem convencional, o romance ressente-se da presença ostensiva da narradora que, tentando marcar distância da protagonista, se intromete o tempo todo com longos e altivos comentários sobre a atitude dela e das demais personagens. Falho como composição, o livro interessa menos pelo valor literário duvidoso e mais pelo que revela sobre o distanciamento da autora em relação às mulheres de sua classe e geração que levavam uma vida insípida como a de Maria Luísa. Atenta às limitações sociais que lhes eram impostas e tendo superado várias delas graças ao talento e à obstinação com que se jogava no trabalho, Lúcia foi ao longo da vida reavaliando suas posições sobre a condição das mulheres. O que permaneceu, porém, foi a recusa em pensar-se como feminista. "Não sou e nunca fui" - palavras dela em artigo de 1954, no qual ressalva que era "forçada a reconhecer que tinha razão Virginia Woolf, quando em A room of one 's own reputava o mundo da cultura um mundo masculino, do qual se viam excluídas as mulheres". E a melhor prova de que ela tinha razão residia na maneira como as escritoras, toleradas como intrusas na literatura, "recebiam o supremo elogio feito a um trabalho feminino": até "parece escrito por homem" (Pereira 1954:24).

Tal reavaliação aparece no final do artigo, centrado nas mulheres na literatura brasileira, escrito sob encomenda e iniciado com uma indagação sobre a melhor forma de enquadrar o assunto: tratar das escritoras ou das personagens femininas na ficção? Lúcia resolve o dilema com um argumento certeiro, focado na existência de pontos comuns, afinidades e analogias entre "as heroínas literárias, as figuras históricas e as criaturas de carne e osso que na literatura labutam", decorrentes do "estatuto social feminino, a 
refletir-se igualmente na ficção e na existência de todos os dias, nas intrigas dos romances e no lugar às mulheres concedido na sociedade, nos anseios das personagens fictícias e no destino das moças de verdade, principalmente as de outrora" (1954:17-18).

Leitora inveterada e historiadora competente da literatura brasileira, Lúcia exercita essa dupla habilitação no andamento do artigo, escrito quatro anos depois de seu livro mais importante, História da literatura brasileira: prosa de ficção (1950), com o qual se equiparou - e para muitos, suplantou — ao que de melhor havia sido escrito sobre o tema até então. Com um texto ágil, Lúcia faz uma incursão pela história literária e social do país, repertoria as personagens femininas e mostra os nexos que as uniam às mulheres reais. “Dessas doces donzelinhas, ariscas e sonsas, das ácidas donzelas que, não encontrando marido, se agregavam a parentes, em suas casas vegetando quase como aias, dessas casadas tementes aos maridos ou sorrateiramente os traindo, dessas matriarcas decididas, não raro despóticas, compunha-se a sociedade real, e a que povoava a ficção" (1954:22).

O estilo da autora mostra o quanto ela se deixara impregnar pelas leituras de Machado de Assis e pelo ensaísmo de Gilberto Freyre, sobre quem escreveu várias vezes, uma delas no livro Gilberto Freyre: sua ciência, sua filosofia, sua arte (1962). Entre os 64 colaboradores que integram o volume, figuram alguns dos maiores nomes da intelligentsia brasileira - de Antonio Candido a Carlos Drummond de Andrade. Dentre eles, apenas duas mulheres: Carolina Nabuco e Lúcia, que comparece com o artigo "A valorização da mulher na sociologia histórica de Gilberto Freyre". Visto a partir desse ângulo, a obra do antropólogo pernambucano mostra-se pioneira no tratamento do tema e ganha novos matizes pelo alcance da interpretação de Lúcia, avessa aos enquadramentos simplistas e às oposições rígidas no domínio das relações de gênero, numa posição bem distinta da narradora empertigada de seu romance de estréia.

\section{Patrícia Galvão: de menina levada à musa inventada do modernismo}

Polêmica, irreverente, emancipada. Tais são os qualificativos que marcaram o imaginário construído em torno da figura pública de Patrícia Galvão. Ou simplesmente Pagu. Apelido que recebeu aos 18 anos do poeta Raul Bopp e com o qual se tornou conhecida nos anos 1920 quando, ainda colegial, fazia às vezes de mascote do modernismo paulista e de "boneca"9 do casal Tarsila e Oswald de Andrade. Essa fulgurante inserção no universo de sociabilidade da vanguarda da época aconteceu antes do romance avassalador 
de Patrícia com Oswald, do nascimento do filho de ambos em 1930 e da entrada do casal no Partido Comunista em 1931. A isso se sucedeu uma série de acontecimentos que marcaram a vida de Patrícia Galvão no decênio de 1930: a mudança para o Rio de Janeiro em 1932, a viagem pelo mundo em 1934 (quando estréia como repórter), os meses que morou em Paris (sem Oswald e o filho), onde foi presa como militante comunista estrangeira. Repatriada, voltou ao Brasil em 1934 e, por duas vezes, em 1935 e 1938, esteve novamente na prisão.

Mas antes disso, estreara como ficcionista, aos 23 anos, com Parque industrial, considerado o primeiro romance proletário brasileiro. ${ }^{10}$ Publicado com o pseudônimo Mara Lobo, por imposição do Partido, o livro teve tiragens e divulgação pequenas e foi pago por Oswald de Andrade. Recebido com ressalva pela crítica, foi depreciado pelo poeta católico Murilo Mendes que, em resenha publicada no Boletim de Ariel (1933:317) afirmou tratar-se de "uma reportagem impressionista, pequeno-burguesa, feita por uma pessoa que está com vontade de dar o salto mas não deu [...] Parece que para a autora o fim da revolução é resolver a questão sexual". ${ }^{11}$

Tal apreciação seria revista à medida que arrefecia o embate político e ampliava-se o reconhecimento da perspectiva inovadora de Patrícia Galvão, que situou a trama no espaço urbano de São Paulo, conjugando luta de classes e luta entre os sexos. De valor literário desigual, proporcional ao tom panfletário utilizado para salientar as mazelas do capitalismo, o livro é importante como "documento social e literário, com uma perspectiva feminina e única do mundo modernista de São Paulo" (Jackson apud Galvão 2006:9).

Transposição de experiências vividas por Patrícia Galvão como militante comunista atenta às transformações produzidas na cidade pela industrialização, pela imigração e pela alteração nos padrões de sociabilidade e interação entre as classes, o romance mescla observações ousadas para a época com frases pueris sobre a luta social. Valendo-se da posição de classe das personagens femininas e de sua localização no espaço urbano e industrial, apresenta uma trama simples, na qual mais importante que o conteúdo da história parecem ser as caracterizações dos tipos sociais que transitam e interagem pela cidade. "Enquanto as fêmeas da burguesia descem de Higienópolis e dos bairros ricos para a farra das garçonnières e dos clubs, a criadagem humilhada, de touquinha e avental, conspira nas cozinhas e nos quintais dos palacetes. A massa explorada cansou e quer um mundo melhor" (Galvão 2006:106).

Sete anos depois da publicação de Parque industrial, Patrícia já não alimentava a mesma visão da dinâmica da luta social, convertida em ficção no romance de estréia. Depauperada e magérrima, em razão das adversida- 
des que enfrentara como prisioneira política do regime ditatorial de Vargas, ela rompe definitivamente com o Partido Comunista em 1940 e se casa com Geraldo Ferraz (1905-1979), com quem entrou pra valer na cena cultural e viveu até o final da vida.

Do casamento de ambos, nasceu o segundo filho de Patrícia, Geraldo Galvão Ferraz, que se tornou jornalista como os pais e é o principal responsável pela publicação da autobiografia que sua mãe redigiu em 1940, sob a forma de carta, editada em 2005 com o título Paixão Pagu: a autobiografia precoce de Patrícia Galvão. Da leitura desta carta, sobressai uma mulher bem mais complexa do que a visão que vem sendo construída sobre ela desde os anos 1980 quando, depois de um período de relativo silêncio, foi súbita e acertadamente recuperada pelo poeta concretista Augusto de Campos. O livro Pagu: vida e obra, que ele organizou e publicou em 1982, trouxe Patrícia de volta à cena cultural e política. Figura emblemática do feminismo que despontava na época, símbolo da mulher emancipada, escritora concretista "avant la lettre", defensora intransigente da liberdade de expressão, ela virou uma espécie de ícone. Sua fama chegou a lugares inesperados. "Pagu se multiplicou - sublinha Geraldo Galvão Ferraz (2005:13) — em balés, espetáculos teatrais. Emprestou o nome a centros culturais, livrarias e até butiques".

Em virtude da fama crescente, era previsível que uma parte da história e da personalidade que lhe conferiu tônus - se perdesse para dar lugar a enredos edulcorantes, afeitos, enquanto forma narrativa, às fabulações míticas. Da menina levada à mulher liberada foi um passo, dado menos por Patrícia, na condição de protagonista, e mais pelos intérpretes que a tomaram como heroína de suas histórias. Não que ela não fosse heroína e protagonista. E sim que não fosse tanto quanto alardeado, como prova a longa carta que ela escreveu em 1940 para Geraldo Ferraz, quando tinha 30 anos e vivia o auge do sofrimento provocado pelos quatro anos passados na prisão durante o regime ditatorial do Estado Novo. Redigida com furor e paixão, a carta é um acerto de contas com o passado, a família, o casamento com o modernista Oswald de Andrade, a opção pela militância política nos quadros do Partido Comunista.

Várias são as leituras possíveis dessa "autobiografia precoce" escrita por uma mulher marcada pelo sofrimento que, quando menina, se via como uma "moleca impossível", à margem das outras vidas, esperando uma "oportunidade de evasão" (apud Ferraz 2005:57). Tal oportunidade veio antes de seu ingresso no círculo de sociabilidade dos modernistas. Aos 13 anos, em meio a um romance sem alarde, ela consumou o primeiro "fato consciente" de sua vida: a "entrega do próprio corpo". Entrega no sentido amplo, como dádiva de si e não só de busca do prazer sexual. 
A um só tempo "acima" e "abaixo" da experiência erótica, o amor não se realizou como experiência corporal plena com o primeiro namorado, de quem engravidou e abortou aos 14 anos. Tampouco com Oswald de Andrade, por quem nutria sentimentos contraditórios de admiração, repulsa e atração, a ponto de afirmar categoricamente que nunca o amou, nem no início do romance. Por não "dar importância ao ato sexual", entregou-se a ele "com indiferença, talvez um pouco amarga". O que os ligava era uma curiosidade imensa, o prazer das leituras, as conversas intermináveis, a opção de ambos pela militância política no Partido Comunista, o filho, Rudá de Andrade.

A maternidade, longe de apaziguá-la, foi vivida como uma experiência esgarçada. O amor pelo filho, repleto de ambivalências, sujeitava-se aos desígnios da luta política e à agenda do Partido. Várias foram as vezes em que Rudá ficou sob os cuidados de Oswald enquanto Patrícia, envolvida até a raiz dos cabelos na militância, ausentava-se de casa por longos períodos. Não há espaço para registrar aqui o itinerário de suas mudanças, viagens e ausências. Mas é importante destacar que embora os deslocamentos sucessivos de Patrícia passem ao largo das convenções então dominantes no plano da experiência amorosa e da maternidade, nem por isso sua trajetória foi isenta delas. Embora veladas, elas se deixam apanhar num lugar diverso do esperado para uma mulher que fez fama e nome como símbolo da irreverência e da emancipação no domínio sexual e dos costumes. Onde? $\mathrm{Na}$ busca intensa e deliberada de Pagu por uma transcendência de si e na entrega baseada no sacrifício. Nessa estrutura de sentimentos edificantes, que por tantos séculos marcou a vida de santos e das mulheres reclusas em conventos, encontra-se o núcleo denso que amarra as pontas partidas de sua militância, maternidade e experiências amorosas. Descentrada em relação à matriz religiosa da qual derivava força e sentido, uma vez que Pagu era e permaneceu agnóstica, ela migrou para o terreno profano da política. Luta de classes e luta política conjugaram-se em sua militância ao longo dos anos 1930 com uma obediência estrita às diretrizes do Partido, conformando uma vivência de gênero no registro da sujeição e do apagamento de si.

À medida que o relato sofrido e apaixonado vai tomando corpo na carta endereçada a Ferraz, mais se evidenciam as ligações entre a sexualidade "seqüestrada", a maternidade partida e a militância como exercício de transcendência baseado no auto-sacrifício. Dessa figuração sobressai uma mulher dilacerada, que deixa na sombra a Patrícia/Pagu lânguida dos anos 1920, de olhos enevoados e misteriosos, cabelos fartos e boca bem delineada pelo batom vermelho, que marcou a iconografia do modernismo paulista e o imaginário social em torno dela. Entrega e submissão são os dois eixos centrais de sua trajetória até o final dos anos 1930. E é justamente essa fruição 
no sofrimento que parece conferir sentido à maneira como ela vive o amor, a militância política e a maternidade, para espanto do leitor embalado pela visão libertária que se construiu sobre ela a partir dos anos 1980.

Com a mesma intensidade que vivera a militância política na década de 30, Patrícia se lançaria de corpo e alma na militância cultural nas décadas seguintes. Tal deslocamento de energias não se deu no vazio universalista das abstrações psicologizantes. Ao contrário, fincou-se no solo intelectual e cultural da cidade de São Paulo dos anos 1940. Primeiro, pelas páginas do jornal A Vanguarda Socialista, de orientação trotskista, que se opunha ao Partido Comunista. Nele, Patrícia teve um papel importante, atuando como crítica literária e de cultura, enquanto a maioria dos colaboradores - entre eles, Geraldo Ferraz, o secretário do jornal - mostravam-se mais preocupados com os problemas políticos e sociais. ${ }^{12}$ Contrapondo-se ao realismo socialista e ao stalinismo nas colunas que escrevia para o jornal, não foram poucas as vezes em que Patrícia defendeu "a independência e a liberdade do escritor acima de tudo", batendo de frente em relação à "contingência do servilismo que o Partido [impunha] aos seus militantes" (apud Facioli 1985:150). ${ }^{13}$

Com o fim de A Vanguarda Socialista, Patrícia Galvão e Geraldo Ferraz jogaram-se em um novo desafio: o Suplemento Literário do Diário de S. Paulo, criado pelo casal em 1946 e fechado em 1955. Em meio ao processo de metropolização da capital paulista, assistia-se também ao agenciamento de novas articulações entre o jornalismo e as manifestações de ponta no âmbito da cultura erudita da cidade (Neves 2005). Nesse ir e vir entre a imprensa e a cena cultural mais ampla, desenhava-se a atuação de Patrícia, iluminada pela parceria amorosa e de trabalho com Geraldo Ferraz. Não era a primeira vez que eles faziam um empreendimento conjunto. No ano anterior, quando ainda participavam da redação do jornal A Vanguarda Socialista, publicaram o romance que escreveram a quatro mãos, $A$ famosa revista. Mas foi no Suplemento do Diário de $S$. Paulo que o empenho de ambos em divulgar o que de mais importante estava acontecendo na cena cultural, literária e artística da época concretizou-se em base mais profissional.

Diferente dos jovens universitários que em 1941 lançaram a revista Clima - entre eles Gilda de Mello e Souza - e que no final da década seguinte seriam os principais articuladores do Suplemento Literário do jornal O Estado de S. Paulo, Geraldo Ferraz e Patrícia Galvão nunca freqüentaram a universidade. Entre outras razões, pela ausência de condições materiais, no caso de Ferraz, que teve uma infância difícil, marcada pela orfandade precoce - ou sociais, no caso de Pagu, cujos horizontes familiares, em termos do esperado para a formação de uma moça de sua classe na época, 
não ultrapassavam a conclusão da Escola Normal. Coisa que ela de fato fez em 1928, aos 18 anos de idade.

Ao longo dos anos 1930 e principalmente na década de 1940, já casado com Patrícia e mergulhado na rotina diária do jornalismo, Ferraz dedicouse com afinco à crítica de arte. Como jornalista profissional, divulgou suas avaliações sobre a pintura não-acadêmica. Paralelamente, participou da organização de eventos importantes ligados às artes plásticas, prefaciou catálogos de exposições, entrevistou diversos pintores. A partir de 1946 e nas páginas do Suplemento Literário do Diário de S. Paulo, Geraldo Ferraz dedicou-se integralmente à crítica de arte e à divulgação da arquitetura moderna. Enquanto isso, Patrícia Galvão fez crítica literária. Juntos, contribuíram para calçar essas duas modalidades de intervenção em bases jornalísticas mais sólidas. Pioneiros na criação de um suplemento cultural de vida curta, eles construíram uma parceria amorosa e de trabalho que dá o que pensar. Ela aponta para o "trânsito de mão dupla de um casal de jornalistas-intelectuais, representantes da vanguarda, que procuram fora das rotinas das redações reconhecimento no meio cultural, mas que, de modo contraditório, inserem-se nele devido em grande medida às suas atividades nos jornais" (Neves 2005:22).

\section{Gilda de Mello e Souza: ensaísta acadêmica}

Ao contrário de Patrícia Galvão e Lúcia Miguel Pereira, intelectuais autodidatas cuja produção se nutriu, de início, do clima de radicalismo político dos anos 1930 - a militância no Partido Comunista, no caso de Pagu, ou o movimento de renovação do catolicismo e de suas redes no âmbito do jornalismo e do universo editorial, no caso de Lúcia - Gilda de Mello e Souza firmou-se como intelectual na intersecção da influência do "papa" do modernismo paulista, Mário de Andrade, seu primo em segundo grau, com a formação universitária que recebeu na Faculdade de Filosofia da Universidade de São Paulo. Intelectual de perfil acadêmico, sua marca encontra-se em ensaios e livros que escreveu, e não em artigos para a imprensa, numa situação diversa das outras duas críticas que fizeram nome no jornalismo e nas revistas literárias.

Reconhecida sobretudo como crítica de cultura, Gilda de Mello e Souza estreou em Clima em 1941. Como membro do grupo que editava a revista, ela partilhava com os demais integrantes uma posição singular no sistema cultural paulista, resultante da recuperação que fizeram de elementos centrais da atividade intelectual do passado - o ensaísmo e a crítica - e sua 
atualização em moldes acadêmicos. Como críticos, divergiram dos modernistas - escritores e artistas em sua maioria - mas repartiram com eles o gosto pela literatura e pela inovação no plano estético e cultural. Como universitários, contribuíram para a sedimentação intelectual da tradição modernista. Como críticos e universitários, diferenciaram-se dos cientistas sociais em sentido estrito, não só pela escolha temática, como pela forma de tratamento aplicada aos assuntos. No lugar do estudo monográfico especializado, o ensaio, as visadas amplas, a localização do objeto cultural num sistema abrangente de ligações e correlações (Pontes 1998).

Quando jovem, Gilda fez algumas incursões pela ficção. Em 1941 estreou com o conto "Week-end com Teresinha". A personagem, uma menina do interior, às vésperas de completar 10 anos e às voltas com as relações familiares, os amigos, a sexualidade latente, os afazeres e o tédio provocado pelas aulas de piano, a vontade de ser bailarina, vive com ansiedade a proximidade da festa de seu aniversário, estragada por uma súbita chuva forte. Mesclando a caracterização psicológica com a descrição objetiva do universo familiar de classe média de Teresinha, Gilda entrelaça o tema do aniversário frustrado à sexualidade em mutação da personagem pré-adolescente. O título da história não parece fora de propósito. Ao contrário, "obedecendo ao gosto da autora pelos ângulos disfarçados e pela composição descentrada, ele tem algo de promessa... futura" (Arêas 1996:25).

A estréia de Gilda de Mello e Souza na ficção continha a promessa da escritora plena que ela poderia vir a ser. Mas não foi isso que aconteceu. Enquanto seus amigos universitários, envolvidos como ela com a publicação de Clima, foram brindados com elogios rasgados pela importante contribuição que vinham dando como críticos de cultura, Gilda recebeu uma única avaliação, assim mesmo enviesada, da parte do modernista Sérgio Milliet. A seu ver, "a novíssima" geração surgia com "grandes possibilidades de vitória" no plano do ensaio e da crítica, mas não no âmbito da ficção. ${ }^{14}$ A avaliação desfavorável do crítico não teve a princípio o efeito paralisante que se poderia esperar. No final de 1941, Gilda publicou o segundo conto, "Armando deu no macaco", centrado nos dilemas e nas frustrações de um funcionário público, com sonhos de escapar do cotidiano banal e repetitivo. O terceiro e último conto que Gilda escreveu para Clima data de abril de 1943. Em "Rosa Pasmada", a autora pinça os desencontros de um casal. Roberto, o marido, quer evadir-se do casamento sufocante, mas não consegue. Lúcia, ao contrário, agarra-se cada vez mais às lembranças do passado de ambos. Construindo um "olhar de esguelha", a autora faz deslizar, de forma quase imperceptível, o ponto de vista masculino para o feminino, tornando "ambíguas as racionalizações" e empurrando "a solução do conflito para um beco 
sem saída" (Arêas 1996:26). Sua capacidade para retirar de um fragmento do cotidiano todas as implicações psicológicas que permeiam o desencontro amoroso, aliada ao talento para tratar o tema na linguagem concisa do conto, não foi suficiente para que ela desse continuidade à carreira de escritora. Seriam necessários mais quinze anos e uma nova conjuntura para que ela voltasse a publicar o quarto e último conto: "A visita", lançado em 1958 no Suplemento Literário de O Estado de S. Paulo.

A insegurança poderia ser apontada como uma das razões que levaram Gilda de Mello e Souza a abandonar a ficção no período de Clima. Mas se assim o foi, longe de ser um problema pessoal, tal sentimento é a expressão condensada da situação vivida pelas mulheres de sua geração. O acesso à formação intelectual que tiveram na Faculdade de Filosofia e à sociabilidade universitária permitiu a várias delas reorientar o papel social para o qual haviam sido educadas: mães e donas de casa. O impacto da experiência renovadora propiciada pela Faculdade foi enorme, sobretudo para aquelas que efetivamente tentaram inventar para si um novo destino, como foi o caso de Gilda. Mas isso se deu à custa de conflitos, inseguranças e dilemas muito específicos, principalmente no início, quando não se sentiam socialmente seguras para se inserirem no campo intelectual predominantemente masculino da época.

Nesse contexto de redefinição do trabalho intelectual e de transformação das relações de gênero, Gilda abandonou a ficção. Seu gesto teve um sentido preciso: recusar a posição que os companheiros da revista lhe atribuíram. Insurgir-se contra as duas modalidades socialmente mais adequadas de expressão intelectual para as mulheres na época, a ficção e a poesia, foi talvez o seu "primeiro ato de liberdade" (Mello e Souza 1981-84:147), ainda que arrevesado. Se o grupo de Clima foi pródigo em encontros afetivos que deram certo, foram poucos, no entanto, os casais que conseguiram realizar carreiras paralelas, como Antonio Candido e Gilda. Quando a revista foi lançada em 1941, embora Gilda tivesse uma formação acadêmica em filosofia e sociologia, escreveu apenas duas críticas literárias e jamais se aventurou nas artes plásticas. Na revista, Lourival Gomes Machado respondia pela crítica de artes e Antonio Candido pela crítica literária. Mas tal atribuição, longe de ser apenas uma questão de divisão interna do trabalho intelectual, expressa a maneira como eram vividas as relações de gênero no interior do grupo. Aos homens couberam as posições e os temas nobres: a cultura e a editoria das seções permanentes. Às mulheres, a "costura" da redação, a função de colaboradoras, a poesia e o conto - na dupla condição de escritoras eventuais e de personagens principais do universo ficcional masculino.

Nas páginas de Clima, Gilda cumpriu o papel de ficcionista oficial do grupo. Seguindo o conselho que Mário de Andrade lhe dera em 1941, ela 
aceitou a sugestão do primo de que seria bom para a revista ter um contista permanente, alguém preocupado exclusivamente com a ficção. Mas rapidamente se deu conta de que o prestígio desfrutado não era suficiente para compensar a ambivalência de seus sentimentos. Os ciúmes e o ressentimento por se dedicar à literatura enquanto os amigos voltavam-se para "as coisas do pensamento", somados à percepção de ser "muito principiante", dificultaram a sua afirmação em Clima. Senão de fato, ao menos - o que já é muito — no plano da auto-representação que conforma uma experiência intelectual vivida inicialmente na chave da insegurança. Que esta insegurança não fosse apenas pessoal, mas fundamentalmente geracional e de gênero, dá bem o quadro das dificuldades enfrentadas pelas mulheres no grupo e fora dele. Sobretudo para aquelas, como Gilda, que ainda não sabiam exatamente o que queriam ser, mas tinham clareza do que não desejam mais: "ser apenas mãe, casar, ter filhos, dirigir a casa, receber e pagar visitas, viver submissa à sombra do marido" (Mello e Souza 1981-84:147).

Rebelando-se também contra o destino socialmente reservado na época às mulheres inconformadas, a ficção ou os versos, Gilda preferiu realizar-se "como um homem" (idem), isto é, como ensaísta, intelectual acadêmica e professora da Faculdade de Filosofia, onde se formou em 1939, antes de se tornar assistente de Roger Bastide. Sob a sua orientação, defendeu em 1950 a tese de doutorado, A moda no século XIX, desenvolvida na forma de um ensaio de sociologia estética.

A intimidade de Gilda com o universo literário — adquirida desde muito cedo, como leitora compenetrada, e reforçada pela influência de Mário de Andrade - seria revigorada pela convivência e a troca intelectual com o marido, Antonio Candido (também ele às voltas com o século XIX para a elaboração de Formação da literatura brasileira) e pela orientação que recebeu de Roger Bastide, sociólogo interessado em todas as manifestações simbólicas da vida social, entre elas, as artes e a literatura. Advém daí um dos trunfos de Gilda que tanto incomodaram Florestan Fernandes, ao lamentar no trabalho da autora a "exploração abusiva da liberdade de expressão" incompatível, a seu ver, com a "natureza de um ensaio sociológico" - e a "falta de documentação empírica de algumas das explanações mais sugestivas e importantes" (Fernandes 1952:139). ${ }^{15}$

Vistas hoje, as restrições emitidas por Florestan em 1952, nas páginas da revista Anhembi, são justamente o ponto alto do trabalho. De um lado, o estilo de exposição; de outro, a desenvoltura com que a autora transita da sociologia para a estética. Valeu-se não só da habilidade para enlaçar o testemunho dos escritores à argumentação analítica que dá tônus ao livro, como também de seus olhos de lince para apreender a moda como uma lin- 
guagem simbólica, plástica o suficiente para expressar idéias e sentimentos difusos, marcar pertencimentos e sublinhar distâncias e distinções sociais. Reconhecendo o comprometimento da moda com as injunções sociais e admitindo, de saída, que a "forma é em larga medida sancionada pela sociedade", Gilda não abre mão da análise estética pois, a seu ver, a moda é arte sim, e de um tipo especial. Para decifrá-la nessa chave é necessário a um só tempo intimidade com o assunto e um conhecimento amplo das formas simbólicas expressas em diversos suportes artísticos (Pontes 2006). Gilda tinha de sobra os dois.

Apesar disso, o tema da tese foi considerado por muitos - e à boca pequena - fútil. Coisa de mulher. Na hierarquia acadêmica e científica da época, que presidia tanto a escolha dos objetos de estudo quanto a forma de exposição e explicação dos mesmos, o estudo de Gilda constituiu "uma espécie de desvio em relação às normas predominantes nas teses da Universidade de São Paulo" (Mello e Souza 1987:7). Sinal eloqüente de um duplo constrangimento. De um lado, da assimetria difusa vivida pelas mulheres no plano das relações intelectuais e institucionais que estavam se construindo dentro e fora da universidade. ${ }^{16}$ De outro lado, do constrangimento decorrente da concepção de sociologia então dominante. Animada por um "espírito" cientificista, afeita à idéia positivista de pesquisa como sinônimo de análise sistemática da realidade, e "encarnada" de forma exemplar na figura do sociólogo Florestan Fernandes, ela expulsou de seus horizontes o ensaio e as dimensões estéticas dos fenômenos sociais. A transferência de Gilda para a área de estética em 1954, bem como a mudança de Antonio Candido para Assis em 1959, após 16 anos de inserção na sociologia (antes de sua volta a São Paulo em 1960 como professor de literatura e não mais de sociologia) são indícios extremamente significativos da oposição entre ciência e cultura que se estabelecera, na época, na Faculdade de Filosofia da Universidade de São Paulo.

\section{Parcerias, trabalho e obra}

Com recursos e meios de expressão distintos, Lúcia, Patrícia e Gilda refletiram sobre os constrangimentos sociais e psicológicos que incidiam sobre a vida das mulheres - delas, de suas contemporâneas e das que as antecederam. Tendo estreado na ficção com Maria Luisa, Lúcia Miguel Pereira procurou distanciar-se da personagem e dos horizontes limitados em que ela e, por extensão, as mulheres de classe média, casadas, convencionalmente católicas e sem perspectivas de uma vida profissional, se moviam. 
A altivez da narradora, tão imbuída de certezas como sua personagem, só que em direções contrárias, transformou-se com o tempo na voz autoral, reflexiva e arguta com que Lúcia enfrentou o assunto espinhoso da condição feminina. Patrícia Galvão, como vimos, apreendeu o tema pela via da industrialização e da luta de classes e pelo prisma das personagens femininas de Parque industrial, sobretudo daquelas com as quais mais se identificava por estarem tão envolvidas, como ela, na luta política. Além de abordá-lo em chave ficcional, Patrícia foi, dentre as três, a que expressou com maior radicalidade a aversão às convenções dominantes no plano da moralidade e da sexualidade. Gilda de Mello e Souza, por sua vez, deslindou a condição das mulheres nos contos e na tese de doutorado sobre a moda, graças à acuidade analítica com que tratou o tema da frustração. Alinhavando as duas frentes expressivas da autora - a ficção e o ensaio acadêmico - a frustração, em certas condições sociais e históricas, parecia-lhe "inalienável ao destino feminino" (Arêas 2007:131) ${ }^{17}$. Por isso, é que ao tratar da moda no século XIX, Gilda foi além das implicações sociológicas e estéticas. Como único "meio lícito de expressão", a moda propiciou à mulher burguesa a "descoberta de sua individualidade". Inquieta e insatisfeita, "refazendo por si o próprio corpo, aumentando exageradamente os quadris, comprimindo a cintura, violando o movimento natural dos cabelos [ela] procurou em si - já que não lhe sobrava outro recurso - a busca de seu ser, a pesquisa atenta de sua alma" (Mello e Souza 1987:100).

Intelectuais vigorosas e mulheres excepcionais, suas trajetórias iluminam os recursos que dispunham e os espaços possíveis de inserção no campo intelectual marcadamente masculino da época. Um deles diz respeito às parcerias amorosas e de trabalho. Se este é um ponto comum entre elas, visto que todas se casaram com intelectuais de prestígio, é preciso sublinhar as diferenças mais significativas nesse domínio, ligadas à maior ou à menor assimetria dessas parcerias. Patrícia e Oswald de Andrade (o mais endinheirado dos modernistas) compõem a mais assimétrica delas, em razão das origens sociais distintas e da brutal diferença de capital cultural e econômico entre eles. No pólo oposto, de menor assimetria, encontram-se Gilda e Antonio Candido, Patrícia e Geraldo Ferraz. Origens sociais e idades semelhantes, carreiras parecidas e interesses intelectuais afinados tornaram essas parcerias mais igualitárias. Na posição intermediária, estavam Lúcia e Otávio Tarquínio de Souza que, além de mais velho, era um homem desquitado quando se casou com ela. Tal estado civil tinha implicações na vida de uma mulher de origem social elevada, como Lúcia, católica e "solteirona" até os 39 anos. Mas pouco afetou uma mulher à frente de seu tempo e de origem social humilde como Patrícia, casada por duas vezes, a primeira delas com 
Oswald, que fez nome como escritor e fama como homem de vida amorosa exuberante e desregrada para os padrões da época.

Além dos graus diversos de assimetria presentes nessas parcerias, é necessário sublinhar os diferentes recursos expressivos de que dispunham ou conquistaram no exercício da atividade intelectual. Isto é, o modo como cada uma delas construiu uma obra com dicção autoral própria e um engate no mercado de trabalho. Lúcia transitou por gêneros diversos - crítica de cultura, história literária, biografia, ficção, literatura infantil - e produziu uma obra vigorosa na exata medida em que fundiu gêneros praticados em separado pelos intelectuais da época, caso de seu marido Otávio, restrito às biografias históricas. Ela tirou partido de suas opções e encontrou meios de aprontar uma contribuição inovadora, inserindo-se no campo intelectual carioca como autora versátil, entre a ficção e a história literária, entre a coluna de jornal e o livro em coleções prestigiosas. Patrícia moveu-se da ficção para a política, e desta para a crítica literária, de teatro e de cultura, arriscando-se em empreitadas inovadoras, como a revista de orientação trotskista e o suplemento cultural em jornal de grande tiragem. Seu maior legado foi a própria vida, junção de mulher emancipada e militante incondicional pela liberdade de expressão. Gilda, por fim, passou da ficção para a sociologia e depois para a filosofia. Autora de uma obra pequena quando comparada à de Antonio Candido, mas tão vigorosa quanto a dele, ela contemplou objetos diversos ao longo da vida moda, literatura, pintura, cinema - e descortinou, com rigor analítico, paixão e escrita desempenada, as formas simbólicas da vida social.

\section{A "palavra" e a "graça": considerações finais}

Uma comparação, mesmo que rápida, entre o campo intelectual no qual se situavam Gilda, Pagu e Lúcia, e o campo teatral, tendo como pinça analítica as relações sociais de gênero, permite contrastar as oportunidades de carreiras e as maneiras distintas de fazer um "nome" que se abriam para as intelectuais e as atrizes, sobretudo para as intérpretes que atuaram em São Paulo nos decênios de 1940 e 1950 - Cacilda Becker, Tônia Carrero, Maria Della Costa, Fernanda Montenegro, Nydia Lícia e Cleyde Yáconis, entre outras - quando a cidade se tornou o pólo modernizador do teatro brasileiro, ofuscando por mais de uma década a cena carioca (Brandão 1988). Nesse período e nas palavras da atriz Maria Della Costa, "as mulheres mandavam no teatro"18 e, por isso mesmo, conquistaram mais cedo do que em outras áreas o "nome próprio" e tudo que dele decorre: prestígio, autoridade e reconhecimento (Bourdieu \& Delsaut 1975). 
Enquanto as três intelectuais abordadas neste artigo foram mulheres excepcionais, no sentido de que, ao se inserirem num campo marcadamente masculino, sofreram - com maior ou menor intensidade — os reveses dessa condição, e fizeram valer o capital cultural conquistado por meio de uma escolarização elevada ou de relações sociais entranhadas na atividade cultural, as atrizes mencionadas acima fizeram nome e firmaram a autoridade artística num domínio menos culto e escolarizado, e bem mais aberto à presença feminina. Não havia no período em que entraram em cena, escolas ou faculdades de teatro e artes cênicas. E quando a primeira delas foi criada, a Escola de Arte Dramática, por iniciativa de Alfredo Mesquita, no mesmo ano da inauguração do Teatro Brasileiro de Comédia (1948), algumas dessas atrizes, como Cacilda Becker, passaram por lá como professoras e não como alunas. Discípulas mesmo elas foram dos diretores estrangeiros, estes sim detentores de uma elevada cultura teatral. A formação que deles receberam foi filtrada e redesenhada nas companhias que montaram com a colaboração ativa de seus parceiros.

Mais "feminino" que o campo intelectual no período, ele ilumina, por contraste, os espaços possíveis, os recursos utilizados, os constrangimentos enfrentados por Gilda de Mello e Souza, Patrícia Galvão e Lúcia Miguel Pereira para se fazerem reconhecidas como ensaístas, críticas de cultura e intelectuais. Isto não significa que as clivagens de gênero estivessem ausentes do teatro. Na divisão de trabalho que presidia a carpintaria teatral na época, elas estavam lá, mas com inflexões distintas. Enquanto o trabalho de ator era facultado a homens e a mulheres, o da dramaturgia era privilégio ou atributo dos homens. Entre o pólo mais "feminino" da representação, ocupado por atores e atrizes, e o mais "masculino" da dramaturgia, exercido pelos autores, encontravam-se os diretores e as ensaiadoras, com claro e diferenciado reconhecimento para os primeiros. Nos grupos e nos elencos, a figura da primeira atriz, remodelada pelas concepções do teatro moderno, continuou a ter uma grande centralidade, mesmo quando o nome dela não vinha estampado no nome da companhia. Para a manutenção de tal centralidade, as mulheres fizeram valer a competência adquirida como atrizes, com a anuência e o apoio de seus parceiros. Não aleatoriamente singularizaram ou mesclaram seus nomes artísticos aos de suas companhias.

Bastante distinta era a situação vivida pelas críticas de cultura. Não que seus nomes - ou pseudônimo, como Mara Lobo, com o qual Patrícia Galvão estreou na ficção - não tenham sido estampados nos livros que escreveram. Tampouco que não pudessem galgar posições mais sólidas, decorrentes da autoria e da autoridade intelectual a ela associada, caso de Lúcia Miguel Pereira. Mas sim que as instâncias de controle e de prestígio, ocupadas prio- 
ritariamente pelos homens, só seriam franqueadas às intelectuais - como mostra a trajetória de Gilda de Mello e Souza — bem mais tarde e de forma muito mais tortuosa do que a enfrentada pelos seus colegas da profissão.

Tais considerações não visam essencializar marcadores sociais de gênero e muito menos encapsular as trajetórias das mulheres reais sob o feixe anêmico de uma suposta condição comum de sujeição. O que se pretende é pôr em relação trajetórias, carreiras, parcerias, constrangimentos e recursos alocados em espaços sociais específicos, como são os campos de produção cultural, marcados eles mesmos por clivagens internas de gênero, que replicam com conteúdos específicos as clivagens decorrentes da maior ou menor proximidade que mantêm com o campo político. Quanto mais distante dele, mais a atividade cultural que empreendem é vista e associada ao pólo feminino. Ao contrário, quanto mais próximo dele, maior a associação com o pólo masculino e com os princípios e os estilos socialmente definidos de masculinidade e feminilidade. Se eu estiver correta, tal procedimento explica as maneiras e as razões que levaram o campo intelectual e o do teatro a serem mais ou menos refratários à presença e à atuação das mulheres, no momento em que ambos se inscreviam numa mesma trama cultural urdida pelas metrópoles em expansão, São Paulo e Rio de Janeiro, e pela convergência entre a "palavra", o "gesto" e a "graça". ${ }^{19}$

Recebido em 03 dezembro de 2007

Aprovado em 10 de abril de 2008

Heloisa Pontes é professora do Departamento de Antropologia da Unicamp, pesquisadora do Pagu, Núcleo de Estudos de Gênero da Unicamp e bolsista de produtividade em pesquisa do CNPq. E-mail: <helopontes@uol.com.br> 


\section{Notas}

${ }^{1}$ Este artigo deve muito à leitura de estudos sobre a vida intelectual em outras formações sociais, entre os quais se destacam Auerbach (2007), Bender (1993), Bourdieu (1984, 1992), Chadwick \& Courtivron (1993) Elias (1995), Sarlo (2003), Schorske (1998), Williams (1982).

${ }^{2}$ Cf. Oswald de Andrade, "Diante de Gil Vicente", Ponta de Lança, 1972, pp. 65-66, grifos meus. (Reprodução do artigo publicado em 1944 no jornal O Estado de S. Paulo).

${ }^{3}$ Para uma análise aprofundada da política cultural nesse período, ver Rubino (1991) e Schwartzman et alii (1984).

${ }^{4}$ Sobre a história e o perfil institucional e intelectual dessas faculdades, ver Schwarcz (1993).

${ }^{5}$ Entre os autores e os livros premiados por ela, encontram-se: "Gilberto Freyre, com Casa grande \& senzala, em 1933, Lúcia Miguel Pereira, com Machado de Assis, em 1939, Rachel de Queirós, com As três Marias, José Lins do Regro, com Água mãe" (Gomes 1999:90).

${ }^{6}$ A revelação do nome de Lúcia aconteceu com a publicação de Machado de Assis (estudo crítico-biográfico), editado em 1936. Ele foi resenhado ou comentado por críticos e intelectuais importantes, como Alceu Amoroso Lima, Álvaro Lins, Manuel Bandeira, Monteiro Lobato, Augusto Frederico Schmidt, José Lins do Rego, entre outros. Com essa biografia, Lúcia ganhou o "maior prêmio literário da época, concedido pela Sociedade Felipe d Oliveira". "[...] O livro representou, sem dúvida, uma renovação no tratamento das biografias, mas principalmente uma reabertura nos estudos machadianos [...] acrescentando e até retificando, algumas vezes, o caminho aberto pelos pioneiros como Alcides Maya e Alfredo Pujol, mas sobretudo em Lúcia Miguel Pereira e Augusto Meyer". Cf. "Dados biográficos da autora (nota da editora)". In: Pereira (1988a:12).

${ }^{7}$ Os romances de Lúcia Miguel Pereira foram reeditados em 2006 em um único volume, Ficção reunida, graças à iniciativa da editora da Universidade Federal do Paraná.

${ }^{8}$ Uma parte desse testamento encontra-se transcrita no livro póstumo de Lúcia Miguel Pereira, A leitora e seus personagens, 1992, que reúne textos publicados por ela em periódicos (1931-1943) e em livros. O volume traz um prefácio interessante, de autoria de Bernardo Mendonça, e uma extensa pesquisa bibliográfica feita por Luciana Viégas.

${ }^{9}$ A expressão é do artista plástico Flávio de Carvalho e encontra-se reproduzida no "Roteiro de uma vida-obra" incluído no livro de Campos (org.), 1982, p.320. 
${ }^{10}$ Para uma discussão aprofundada sobre o romance proletário, ver Rossi (2004).

${ }^{11}$ Nessa mesma resenha, Mendes contrapõe o romance de Pagu a Cacau, de Jorge Amado. A seu ver o romance do escritor baiano teria "outra consistência. O autor examina a vida dos trabalhadores de fazenda de cacau com uma visão aguada do problema, e não sacrifica o interesse humano do drama ao pitoresco" (Mendes 1933:317). Agradeço a Luiz Gustavo Freitas Rossi pela indicação dessa resenha.

${ }^{12}$ Ver, nesse sentido, "Entrevista com Edmundo Muniz" (um dos criadores de A Vanguarda Socialista, junto com o crítico de arte Mário Pedroso) em Facioli $(1985: 129)$.

${ }^{13}$ Cf. Patrícia Galvão, "A sementeira da revolução", publicado originalmente em A Vanguarda Socialista, ano I, n.6, 5 de outubro de 1945, reproduzido em Facioli $(1985: 150)$.

${ }^{14}$ A avaliação de Milliet, publicada em agosto de 1941 no quinzenário Planalto, foi reproduzida na revista Clima, n.3, agosto de 1941.

${ }^{15}$ Para uma análise das implicações dessa resenha no contexto das tensões e das disputas na sociologia paulista, consultar Jackson (2007).

${ }^{16}$ Para uma análise exaustiva da situação das mulheres na Faculdade de Filosofia, ver Trigo (1997).

${ }^{17}$ Neste ensaio, Vilma Arêas confirma mais uma vez o acerto de suas reflexões sobre a ficção de Gilda, ao mostrar que no lugar de tratá-la como uma esfera apartada da produção ensaística e crítica da autora, é preciso recompor a trama sutil que as articula e o tema de fundo que as envolve - a frustração - "o grande tema de Gilda de Mello e Souza" (Arêas 2007:131).

${ }^{18}$ Trecho da entrevista que Maria Della Costa concedeu ao jornal A Tribuna de Santos, em 26/02/1984.

${ }^{19}$ Se em alguns contextos a relação entre o teatro, a universidade e a cidade sinaliza caminhos divergentes (Schorske 1998), em outros, ela aponta para trilhas convergentes, que expressam similitudes formais e sociais, como procurei em Intérpretes da metrópole (Pontes 2008). 


\section{Referências bibliográficas}

ALMEIDA, Maria Hermínia Tavares. 2001. "Dilemas da institucionalização das ciências sociais no Rio de Janeiro". In: S. Miceli (org.), História das ciências sociais no Brasil. vol.1, $2^{\text {a }}$. ed. São Paulo: Sumaré. pp. 223-255.

ARÊAS, Vilma. 1996. "Prosa branca". Discurso, 26:19-32.

. 2007. "O motivo da flor". In: Miceli \& Mattos (orgs.), Gilda: a paixão pela forma. Rio de Janeiro: Ouro sobre Azul/ Fapesp. pp. 125-138.

ARRUDA, Maria Arminda do Nascimento. 2001. Metrópole e cultura: São Paulo no meio século XX. Bauru: Edusc.

AUERBACH, Erich. 2007. "La cour et la ville". In: Ensaios de literatura ocidental. São Paulo: Duas Cidades /Ed. 34. pp. 211-278.

BENDER, Thomas. 1993. Intellect and public life: essays on the social history of academic intellectuals in the United States. Baltimore: Johns Hopkins University Press.

BOURdieU, Pierre. 1984. Homo academicus. Paris: Minuit.

- 1992. Les règles de l'art. Genèse et structure du champ littéraire. Paris: Éditions du Seuil.

_. \& DELSAUT, Yvette. 1975. "Le couturier et sa griffe: contribuition à une théorie de la magie". Actes de la Recherche en Sciences Sociales, 1:7-36.

BRANDÃO, Tânia. 1988. Peripécias modernas: Companhia Maria Della Costa. Tese de doutorado em história, UFRJ, Rio de Janeiro, 2 vols.

CANDIDO, Antonio. 1984. "A revolução de 1930 e a cultura". Novos Estudos Cebrap, 2(4):27-32.

. 2004. "Lúcia". In: O albatroz e o chinês. Rio de Janeiro: Ouro sobre Azul. pp. 127-132.
2006. "Literatura e cultura de 1900 a 1945". In: Literatura e sociedade. Rio de Janeiro: Ouro sobre Azul. pp. 117-145.

CAMPOS, Augusto. 1982. Pagu: vidaobra. São Paulo: Brasiliense.

CARVALHO, Maria Alice Resende. 2007. "Temas sobre a organização dos intelectuais no Brasil". Revista Brasileira de Ciências Sociais, 22(65):17-31.

CHADWICK, Whitney \& COURTIVRON, Isabelle (orgs.). 1993. Significant others: creativity \& intimate partnership. New York: Thames and Hudson.

ELIAS, Norbert. 1995. Mozart: sociologia de um gênio. Rio de Janeiro: Zahar.

FACIOLI, Valentim (org.). 1985. Por uma arte revolucionária independente. São Paulo: Paz e Terra.

FERNANDES, Florestan. 1952. "Resenha de A moda no século XIX: ensaio de sociologia estética". Anhembi, 25:139-142.

FERRAZ, Geraldo Galvão. 2005. "A vida dentro de uma pasta preta". In: Ferraz (org.), Paixão Pagu: a autobiografia precoce de Patrícia Galvão. Rio de Janeiro: Agir. pp. 8-13.

GALVÃO, Patrícia. 1985. "A sementeira da revolução". In: V. Facioli (org.), Por uma arte revolucionária independente. São Paulo: Paz e Terra. pp. 150-152.

_. 2006 [1933]. Parque industrial. Rio de Janeiro: José Olympio.

GALVÃO, Maria Rita. 1981. Burguesia e cinema: o caso Vera Cruz. Rio de Janeiro: Civilização Brasileira.

GOMES, Angela de Castro. 1999. Essa gente do Rio... Modernismo e nacionalismo. Rio de Janeiro: Editora Fundação Getúlio Vargas. 
JACKSON, Kenneth. 2006. "Patrícia Galvão e o realismo social brasileiro dos anos 30". In: P. Galvão, Parque industrial. Rio de Janeiro: José Olympio. p. 9.

JACKSON, Luiz Carlos. 2007. "Tensões e disputas na sociologia paulista (19401970)". Revista Brasileira de Ciências Sociais, 22(65):33-49.

LÉVI-STRAUSS, Claude. 1981. Tristes trópicos. Lisboa: Edições 70.

MELLO E SOUZA, Gilda. 1980. "Teatro ao sul". In: Exercícios de leitura. São Paulo: Duas Cidades. pp. 109-116. - 1984. "Depoimento". Língua e Literatura, 10-13:132-156.

- 1987. O espírito das roupas. São Paulo: Companhia das Letras.

MENDES, Murilo. 1933. "Notas sobre Cacau". Boletim de Ariel, 12.

MENDONÇA, Bernardo. 1992. "A leitora e seus personagens: profecias e memória dos anos 30". In: L. M. Pereira, A leitora e seus personagens: seleta de textos publicados em periódicos (1931-1943) e em livros. Rio de Janeiro: Graphia Editorial. pp. xii-xx.

MICELI, Sérgio. 2001a. "Condicionantes do desenvolvimento das ciências sociais". In: (org.), História das ciências sociais no Brasil, v.1, $2^{\mathrm{a}}$. ed. São Paulo: Sumaré. pp. 91-133. - 2001b. Intelectuais à brasileira. São Paulo: Companhia das Letras.

NEVES, Juliana. 2005. Geraldo Ferraz e Patrícia Galvão: a experiência literária do Suplemento Literário do Diário de S. Paulo, nos anos 40. São Paulo: Annablume/ Fapesp.

PEIXOTO, Fernanda. 2001. "Franceses e norte-americanos nas ciências sociais brasileiras (1930-1960)". In: S. Miceli (org.), História das ciências sociais no Brasil, v.1, $2^{a}$.ed. São Paulo: Sumaré. pp. 135-221.

PEREIRA, Lúcia Miguel. 1952. A vida de Gonçalves Dias. Rio de Janeiro: José Olympio.
- 1954. "As mulheres na literatura brasileira". Anhembi, 17(49):17-25.

1962. "A valorização da mulher na sociologia histórica de Gilberto Freyre". In: G. Amado et alii, Gilberto Freyre: sua ciência, sua filosofia, sua arte. Ensaios sobre o autor de Casa-Grande \& Senzala e sua influência na moderna cultura do Brasil, comemorativos do $25^{\circ}$ aniversário da publicação desse livro. Rio de Janeiro: José Olympio. pp. 350-356.

- 1988a [1936]. Machado de Assis (estudo crítico-biográfico). 6 ${ }^{\mathrm{a}}$. ed. Belo Horizonte: Itatiaia; São Paulo: Edusp. - 1988b [1950]. História da literatura brasileira: prosa de ficção (de 1870 a 1920). $6^{a}$. ed. Belo Horizonte: Itatiaia; São Paulo: Edusp.

- 1992. A leitora e seus personagens. Prefácio de Bernardo de Mendonça. Pesquisa bibliográfica, seleção e notas de Luciana Viégas. Rio de Janeiro: Graphia Editorial.

. 2005. "Crítica e feminismo". In: Escritos da maturidade: seletas de textos publicados em periódicos (1944-1959). Pesquisa bibliográfica, seleção e notas de Luciana Viégas. $2^{\mathrm{a}}$. ed. Rio de Janeiro: Graphia Editorial. pp. 111-115. - 2006. Ficção reunida. Curitiba: Ed. da UFRP.

PINHEIRO, Fernando. 2007. "A invenção da ordem: intelectuais católicos no Brasil". Tempo Social, 19:33-49.

PONTES, Heloisa. 1998. Destinos mistos: os críticos do Grupo Clima em São Paulo, 1940-1968. São Paulo: Companhia das Letras. - 2001a. "Entrevista com Antonio Candido". Revista Brasileira de Ciências Sociais, 16(47):5-30.

. 2001b. "Retratos do Brasil: editores, editoras e 'coleções brasiliana' nas décadas de 30, 40 e 50". In: S. Miceli (org.), História das ciências sociais no Brasil, v.1, $2^{\mathrm{a}}$.ed. São Paulo: Sumaré. pp. 419-476. 
. 2006. "A paixão pelas formas: Gilda de Mello e Souza". Novos Estudos Cebrap, 74:87-105.

- 2008. Intérpretes da metrópole. História social e relações de gênero no teatro e no campo intelectual, 1940-1968. Tese de livre-docência apresentada ao Departamento de Antropologia da Unicamp, São Paulo.

RAMASSOTE, Rodrigo. 2006. A formação dos desconfiados: Antonio Candido e a crítica literária acadêmica. Dissertação de mestrado em antropologia, Unicamp, São Paulo.

ROSSI, Luiz Gustavo Freitas. 2004. As cores da revolução: a literatura de Jorge Amado nos anos 30. Dissertação de mestrado em antropologia, Unicamp, São Paulo.

RUBINO, Silvana. 1991. As fachadas da história: os antecedentes, a criação e os trabalhos do Serviço do Patrimônio Histórico e Artístico Nacional, 19371968. Dissertação de mestrado em antropologia, Unicamp, São Paulo.

SARLO, Beatriz. 2003. La pasión e y la excepción. Buenos Aires: Siglo 21 Editores Argentina.

SCHORSKE, Carl. 1998. "Grace and the word: Austria's two cultures and their modern fate". In: Thinking with history: explorations in the passage to modernism. Princeton: University Press. pp. 125-140.

SCHWARCZ, Lilia. 1993. O espetáculo das raças: cientistas, instituições e questão racial no Brasil -1870-1930. São Paulo: Companhia das Letras.

SCHWARTZMAN, Simon; BOMENY, Helena \& COSTA, Vanda. 1984. Tempos de Capanema. Rio de Janeiro: Paz e Terra.

SORÁ, Gustavo. 1998. Brasilianas: la casa José Olympio y la institución del libro nacional. Tese de doutorado em antropologia, PPGAS-Museu Nacional, Rio de Janeiro .
TRIGO, Maria Helena Bueno. 1997. Espaços e tempos vividos: estudo sobre os códigos de sociabilidade e relações de gênero na Faculdade de Filosofia da USP (1934-1970). Tese de doutorado em sociologia, USP, São Paulo.

WILliAMS, Raymond. 1982. "The Bloomsbury fraction". In: Problems in materialism and culture. London: Verso Editions. pp. 148-169. 
Resumo

O artigo analisa as inflexões de gênero no campo intelectual brasileiro, em sua interface com a crítica de cultura e literária, entre os anos de 1920 e 1960, por meio das trajetórias sociais de três mulheres expressivas, que fizeram "nome" como críticas de cultura, ensaístas e escritoras: Lúcia Miguel Pereira, Patrícia Galvão e Gilda de Mello e Souza. As três pertencem a gerações distintas e cobrem o espectro político da época: do comunismo ao socialismo, no caso de Patrícia Galvão, passando pelos círculos dos intelectuais católicos, no caso de Lúcia Miguel Pereira, ou mantendo certa distância destas questões e firmando uma identidade intelectual de tipo acadêmico, como Gilda de Mello e Souza. Vistas em conjunto e em meio aos constrangimentos derivados das relações de gênero, elas delineiam alguns dos espaços possíveis para a atuação intelectual das mulheres na época. Para não essencializar marcadores sociais que só ganham vigor analítico quando postos em relação, o artigo se fecha com uma comparação entre o campo intelectual e teatral, com o propósito de contrastar as oportunidades de carreiras e as maneiras distintas de fazer um "nome" que se abriram para as intelectuais e as atrizes no período.

Palavras-chave Campo intelectual, Crítica de cultura, Relações de gênero, Modernismo, Teatro, Parcerias de trabalho

\section{Abstract}

The article analyses the inflections of gender upon the Brazilian intellectual field, in its interface with literary and cultural critique, from the 1920's to the 1960 's. It focuses on the trajectory of three expressive women who achieved renown as critics of culture, essayists and writers: Lúcia Miguel Pereira, Patrícia Galvão and Gilda Mello e Souza. The three belong to distinct generations and cover the political spectrum of the time: from Communism to Socialism, for Patrícia Galvão, through the intellectual circles of Catholicism, for Lúcia Miguel Pereira, or else maintaining a certain distance from these issues and establishing an academic intellectual identity, in the case of Gilde de Mello e Souza. When taken as a set and in the context of the constraints that derive from gender relations, they delineate some of the possible fields for the intellectual activity of women at the time. So as to avoid essentializing social markers that only become analytically potent when placed in relationship, the article concludes by a comparison of the intellectual and theatrical fields, in order to contrast career opportunities and the distinct ways of making a "name" for oneself that were available to intellectuals and actresses at the time.

Key words Intellectual field, Critique of culture, Gender relations, Modernism, Theatre, Work partnerships 